\title{
Surface methane emissions from different land use types during various water levels in three major drawdown areas of the Three Gorges Reservoir
}

\author{
Le Yang, ${ }^{1,2}$ Fei Lu, ${ }^{1}$ Xiaoke Wang, ${ }^{1}$ Xiaonan Duan, ${ }^{3}$ Wenzhi Song, ${ }^{1}$ Binfeng Sun, ${ }^{1,2}$ \\ Shuai Chen, ${ }^{1,2}$ Qianqian Zhang, ${ }^{1,2}$ Peiqiang Hou, ${ }^{1,2}$ Feixiang Zheng, ${ }^{1}$ Ye Zhang, ${ }^{1}$ \\ Xiaoping Zhou, ${ }^{1,2}$ Yongjuan Zhou, ${ }^{1}$ and Zhiyun Ouyang ${ }^{1}$
}

Received 25 December 2011; revised 26 March 2012; accepted 28 March 2012; published 24 May 2012.

[1] Methane $\left(\mathrm{CH}_{4}\right)$ emissions from the drawdown area of the Three Gorges Reservoir (TGR) have not been thoroughly investigated even though the drawdown area encompasses one third of the reservoir surface. In this study, $\mathrm{CH}_{4}$ emissions from different land uses were measured in the TGR drawdown area. The average diffusive $\mathrm{CH}_{4}$ emissions were 2.61, 0.19, 0.18 , and $0.12 \mathrm{mg} \mathrm{CH}_{4} \mathrm{~m}^{-2} \mathrm{~h}^{-1}$ in rice paddies, fallow lands, deforested lands, and croplands, respectively, and were positively related to the duration of the inundated season among the latter three land uses. On average the drawdown areas studied here (except rice paddies) were sources in the inundated season $\left(0.22 \pm 0.26 \mathrm{mg} \mathrm{CH}_{4} \mathrm{~m}^{-2} \mathrm{~h}^{-1}\right)$ and a sink in the drained season $\left(-0.008 \pm 0.035 \mathrm{mg} \mathrm{CH}_{4}\right.$ $\left.\mathrm{m}^{-2} \mathrm{~h}^{-1}\right)$. The water level was the dominant factor that controlled whether the drawdown area was either inundated or drained, which in turn determined whether the drawdown area was a source or sink of $\mathrm{CH}_{4}$ emissions. The average diffusive $\mathrm{CH}_{4}$ emissions from the fallow lands, croplands, and deforested lands increased as the distance from the dam increased from Zigui $\left(0.10 \pm 0.15 \mathrm{mg} \mathrm{CH}_{4} \mathrm{~m}^{-2} \mathrm{~h}^{-1}\right)$ to Wushan $\left(0.15 \pm 0.29 \mathrm{mg} \mathrm{CH}_{4}\right.$ $\left.\mathrm{m}^{-2} \mathrm{~h}^{-1}\right)$ to Yunyang $\left(0.24 \pm 0.27 \mathrm{mg} \mathrm{CH}_{4} \mathrm{~m}^{-2} \mathrm{~h}^{-1}\right)$, which could reflect different sediment characteristics and water velocities. The total $\mathrm{CH}_{4}$ emission from the drawdown area was estimated to range from 1033.5 to $1333.9 \mathrm{Mg} \mathrm{CH}_{4} \mathrm{yr}^{-1}$, which would account for $42-54 \%$ of the total $\mathrm{CH}_{4}$ emissions from the water surface of TGR.

Citation: Yang, L., et al. (2012), Surface methane emissions from different land use types during various water levels in three major drawdown areas of the Three Gorges Reservoir, J. Geophys. Res., 117, D10109, doi:10.1029/2011JD017362.

\section{Introduction}

[2] Methane $\left(\mathrm{CH}_{4}\right)$ is the second most abundant greenhouse gas in the atmosphere, with a relative contribution of about $20 \%$ of the greenhouse effect, second only to carbon dioxide $\left(\mathrm{CO}_{2}\right)$ [Wuebbles and Hayhoe, 2002]. At the molecular level, however, $\mathrm{CH}_{4}$ can absorb infrared radiation 22 times more efficiently than $\mathrm{CO}_{2}$ over 100 years, thus making it one of the most potent greenhouse gases [Zhuang et al., 2009]. The atmospheric $\mathrm{CH}_{4}$ concentration has more than doubled in the past two centuries [Frankenberg et al.,

\footnotetext{
${ }^{1}$ State Key Laboratory of Urban and Regional Ecology, Research Center for Eco-Environmental Sciences, Chinese Academy of Sciences, Beijing, China.

${ }^{2}$ Graduate University of Chinese Academy of Sciences, Beijing, China.

${ }^{3}$ General Office of Chinese Academy of Sciences, Beijing, China.

Corresponding author: F. Lu, Research Center for Eco-Environmental Sciences, Chinese Academy of Sciences, Beijing 100085, China. (lu_fei@yahoo.cn)

Copyright 2012 by the American Geophysical Union. 0148-0227/12/2011JD017362
}

2005], which is mainly attributed to the effects of fossil fuel combustion, waste management, enteric fermentation, the incineration of biomass, and agricultural and natural wetlands [St. Louis et al., 2000; Marani and Alvalá, 2007]. While not officially acknowledged, artificial reservoirs have been recognized as an important anthropogenic source of $\mathrm{CH}_{4}$ [Duchemin et al., 1995; Soumis et al., 2004; Abril et al., 2005], with global estimates of $4 \mathrm{Tg} \mathrm{yr}^{-1}$ for $\mathrm{CH}_{4}$ or $6 \%$ of the total emissions from natural lakes [Barros et al., 2011].

[3] Several studies have measured $\mathrm{CH}_{4}$ emissions from the water surfaces of reservoirs located in boreal, temperate, and tropical regions [Huttunen et al., 2002; Abril et al., 2005; Demarty et al., 2009]; however, few reports are available on $\mathrm{CH}_{4}$ emissions from drawdown areas [Chen et al., 2009, 2011; Lu et al., 2011]. The drawdown area is the vegetated (or cleared) littoral zone at the edge of the reservoir that experiences cycles between inundation and drainage based on water level of the reservoir, due to seasonal cycles or hydroelectric operations. The drawdown areas in reservoirs are considered "hotspot" zones for $\mathrm{CH}_{4}$ emission [Juutinen et al., 2001; Chen et al., 2009]. Narrow littoral zones may even support most of the lake-wide $\mathrm{CH}_{4}$ release during open water season [Bergström et al., 2007], as 




Figure 1. Location of the sampled sites and plots.

was seen in other studies [Juutinen et al., 2003a, 2003b]. Thus drawdown areas are potentially important $\mathrm{CH}_{4}$ emission sources and contribute to any spatial variability observed in emissions.

[4] A previous study on the Three Gorges Reservoir (TGR) has already shown that newly created marshes in the drawdown area are important $\mathrm{CH}_{4}$ emitters [Chen et al., 2009]. However, only $11 \%$ of the TGR drawdown area is actually occupied by marsh/wetlands with the remaining area dominated by dry lands, such as the deforested lands, croplands, and fallow lands [Ye et al., 2006]. Compared with wetlands, dry lands are very minor $\mathrm{CH}_{4}$ sources [Jiang et al., 2009] and may even act as $\mathrm{CH}_{4}$ sinks [Iqbal et al., 2009]. Low $\mathrm{CH}_{4}$ emissions from flooded dry lands were reported recently on the scale of $0.29 \pm 0.37 \mathrm{mg} \mathrm{CH}_{4} \mathrm{~m}^{-2} \mathrm{~h}^{-1}$ basing on six measurements in different seasons [Chen et al., 2011]. Lu et al. [2011] argued that the drained dryland drawdown areas of TGR might emit lower $\mathrm{CH}_{4}$ emission compared with that reported by Chen et al. [2011], due to the exposure of dry lands. The anaerobic conditions are crucial to $\mathrm{CH}_{4}$ production and transfer because $\mathrm{CH}_{4}$ is mineralized to $\mathrm{CO}_{2}$ by methanotrophic bacteria under aerobic conditions [Topp and Pattey, 1997]. As seasonal fluctuations in the water level cause an alternating cycle between inundated and exposed dry lands that would effect $\mathrm{CH}_{4}$ emissions, sufficient seasonal investigations of emissions from various drawdown land types are required to resolve the temporal and spatial variability. The above mentioned studies of TGR $\mathrm{CH}_{4}$ emissions were quite limited spatially and temporally, and the environmental factors leading to these emission variations were not robustly analyzed [Chen et al., 2009, 2011; Lu et al., 2011]. Thus systematic long-term monitoring on a large spatial scale has been suggested to accurately assess the total $\mathrm{CH}_{4}$ emission from TGR drawdown areas.

[5] In this study, $\mathrm{CH}_{4}$ emissions were measured at four types of land (fallow land, cropland, deforested land, and rice paddies) in the drawdown area of TGR from November
2009 through January 2011. Our specific objectives were to (1) estimate the contribution of the drawdown area to total $\mathrm{CH}_{4}$ emissions from TGR, (2) assess the effect of land use on $\mathrm{CH}_{4}$ emissions in the drawdown areas, (3) analyze the spatiotemporal variations in $\mathrm{CH}_{4}$ emissions from different land types, and (4) determine any factors that may influence $\mathrm{CH}_{4}$ emission in the TGR drawdown area.

\section{Methods and Materials}

\subsection{Site Description}

[6] TGR is located within the watercourse of the Yangtze River, which has been flooded since 2003. The TGR is about $660 \mathrm{~km}$ in length, and has a surface area of $1084 \mathrm{~km}^{2}$, including the drawdown area of $450 \mathrm{~km}^{2}$. Water levels in TGR fluctuate seasonally by $30 \mathrm{~m}$. The water level is held at $145 \mathrm{~m}$ during the flood season (June-August) to control flooding, which drains the drawdown area. The water level is gradually increased to $175 \mathrm{~m}$ after the flood season in order to increase the efficiency of electricity generation [Zhou et al., 2010]. The capacity to generate electricity at TGR was 18.2 million $\mathrm{kW}$ in 2010 (84.7 billion $\mathrm{kWh}$ of electricity were actually produced in 2010), making the TGR the largest hydroelectric producer in the world.

[7] The TGR is located in a subtropical monsoon climate zone with an annual mean temperature of $16.3-18.2^{\circ} \mathrm{C}$ and annual precipitation of 987-1326 mm [Guo et al., 2007]. Nearly $80 \%$ of the precipitation falls in the hot-wet season (April-September); only 20\% falls in the cool-dry season (October-March) [Guo et al., 2007]. This study was carried out at three sites in the drawdown area near Zigui $\left(30^{\circ} 51^{\prime} \mathrm{N}\right.$, $\left.110^{\circ} 58^{\prime} \mathrm{E}\right)$, Wushan $\left(31^{\circ} 03^{\prime} \mathrm{N}, 109^{\circ} 51^{\prime} \mathrm{E}\right)$, and Yunyang $\left(30^{\circ} 56^{\prime} \mathrm{N}, 108^{\circ} 39^{\prime} \mathrm{E}\right)$, which are $2 \mathrm{~km}, 120 \mathrm{~km}$ and $240 \mathrm{~km}$ upstream from the Three Gorges Dam (Figure 1).

[8] Three kinds of plots (fallow land, cropland, and deforested land) at each site were selected in September 2009 when the plots were drained and the water level was 
Table 1. Elevation, Duration of Inundation, $\mathrm{pH}$, and Soil Carbon and Nitrogen Levels at the Sampled Sites ${ }^{\mathrm{a}}$

\begin{tabular}{|c|c|c|c|c|c|c|}
\hline Site & Plot & Elevation (m) & Inundated Duration (d) & Soil pH & Organic $\mathrm{C}\left(\mathrm{g} \mathrm{kg}^{-1}\right)$ & Total $\mathrm{N}\left(\mathrm{g} \mathrm{kg}^{-1}\right)$ \\
\hline \multirow[t]{4}{*}{ Zigui } & Fallow land & 149 & 314 & $6.42 \pm 0.16^{(a)}$ & $10.72 \pm 2.67^{(\mathrm{a})}$ & $0.78 \pm 0.17^{(\mathrm{a})}$ \\
\hline & Cropland & 160 & 175 & $6.64 \pm 1.01^{\text {(a) }}$ & $11.18 \pm 3.56^{(\mathrm{a})}$ & $0.90 \pm 0.19^{(\mathrm{a})}$ \\
\hline & Deforested land & 148 & 326 & $6.21 \pm 0.32^{(\mathrm{a})}$ & $11.44 \pm 1.65^{(\mathrm{a})}$ & $0.85 \pm 0.14^{(\mathrm{a})}$ \\
\hline & Average & 152 & 272 & $6.42 \pm 0.22$ & $11.11 \pm 0.36$ & $0.81 \pm 0.12$ \\
\hline \multirow[t]{4}{*}{ Wushan } & Fallow land & 151 & 296 & $8.00 \pm 0.20^{(\mathrm{a})}$ & $8.11 \pm 1.13^{(\mathrm{a})}$ & $1.05 \pm 0.10^{\text {(a) }}$ \\
\hline & Cropland & 157 & 229 & $8.28 \pm 0.08^{(\mathrm{a})}$ & $12.39 \pm 2.43^{(\mathrm{b})}$ & $1.26 \pm 0.24^{(\mathrm{b})}$ \\
\hline & Deforested land & 161 & 167 & $8.12 \pm 0.10^{(\mathrm{a})}$ & $11.64 \pm 2.69^{(\mathrm{b})}$ & $1.19 \pm 0.20^{(\mathrm{a}, \mathrm{b})}$ \\
\hline & Average & 156 & 231 & $8.13 \pm 0.14$ & $10.71 \pm 2.29$ & $1.17 \pm 0.11$ \\
\hline \multirow[t]{5}{*}{ Yunyang } & Fallow land & 149 & 314 & $8.29 \pm 0.10^{(\mathrm{a})}$ & $4.68 \pm 2.38^{(\mathrm{b})}$ & $0.57 \pm 0.17^{(\mathrm{b})}$ \\
\hline & Cropland & 160 & 175 & $8.63 \pm 0.50^{(\mathrm{a})}$ & $2.66 \pm 0.57^{(\mathrm{a})}$ & $0.34 \pm 0.04^{(\mathrm{a})}$ \\
\hline & Deforested land & 150 & 305 & $8.25 \pm 0.05^{(a)}$ & $3.55 \pm 0.43^{(b)}$ & $0.48 \pm 0.18^{(\mathrm{b})}$ \\
\hline & Average & 153 & 265 & $8.39 \pm 0.21$ & $3.63 \pm 1.01$ & $0.46 \pm 0.12$ \\
\hline & Rice paddies & 172 & 214 & $8.45 \pm 0.26^{(a)}$ & $16.49 \pm 2.47^{(\mathrm{c})}$ & $2.69 \pm 0.83^{(\mathrm{c})}$ \\
\hline
\end{tabular}

${ }^{a}$ The letters (a), (b), and (c) indicate significant difference $(\mathrm{p}<0.05)$ at each site. Values are the mean \pm SE (standard error). The average values of Yunyang do not include the values measured in the rice paddies.

below $146 \mathrm{~m}$. A rice paddy (Oryza sativa), located at an elevation of $172 \mathrm{~m}$ in Yunyang, was added in June 2010 as a kind of agricultural wetland; thus making 10 experimental plots over 3 sites (Table 1). As lands below $160 \mathrm{~m}$ were frequently inundated by normal water level fluctuations or summer floods, only lands above $160 \mathrm{~m}$ were reclaimed for crop cultivation. Croplands were thus only located in the upper zone of the drawdown area at each of the three sites, while fallow and deforested lands were located in the lower zone, except for the deforested land in Wushan. Maize (Zea mays L.) was grown in the croplands of Zigui and Wushan, and sesame (Sesamum indicum L.) was grown in the cropland of Yunyang and the deforested land in Wushan. In the deforested lands, trees were cut down before the reservoir was impounded and many stumps were left on site.

\section{2. $\mathrm{CH}_{4}$ Emission Measurements}

[9] $\mathrm{CH}_{4}$ emissions were measured using the static chamber method [Duchemin et al., 1995]. Two kinds of static chambers were deployed: 1) a floating static chamber for measuring $\mathrm{CH}_{4}$ emissions from the water surface, and 2) a closed static chamber was used for measuring $\mathrm{CH}_{4}$ emissions from dry land or rice paddies during the drained season. The same chambers were used for measuring $\mathrm{CH}_{4}$ emissions from dry lands both in the inundated and drained seasons. The floating static chamber $(65 \mathrm{~cm}$ in length $\times$ $45 \mathrm{~cm}$ in width $\times 40 \mathrm{~cm}$ in height) consisted of a plastic box without a cover that was wrapped in light-reflecting and heatproof films to prevent temperature variation inside the chambers; in addition, plastic foam collars were fixed onto opposite sides of the chamber. The headspace height inside the chamber was about $30 \mathrm{~cm}$. When the fallow lands, croplands, and deforested lands were drained, the abovedescribed chambers were placed on permanently positioned aluminum bases $(65 \mathrm{~cm}$ in length $\times 45 \mathrm{~cm}$ in width $\times 10 \mathrm{~cm}$ in height) with water grooves on top and inserted into the soil in order to ensure a tight fit at the air-soil interface. To avoid disturbing plant respiration and photosynthesis, any new growth grasses around the base were cleared before the gas samples were collected. A closed, static, steel frame chamber $(50 \mathrm{~cm}$ in length $\times 50 \mathrm{~cm}$ in width $\times 75 \mathrm{~cm}$ in height for measuring emissions from rice paddies) was covered in polyethylene plastic film ( $85 \%$ transparent) and used to collect gas samples from rice paddy [Duan et al.,
2005; Zheng et al., 2011a]. A silicone tube $(0.6 \mathrm{~cm}$ and $0.4 \mathrm{~cm}$ outer and inner diameters, respectively) was inserted into the upper side of the chamber to collect gas samples and another silicone tube was inserted into the chamber to keep air pressure balanced between the inside and outside of the chamber. All measurements were performed in triplicate.

[10] In either flooded or drained seasons, the gases in the headspace of the chamber were collected into air-sampling bags (0.5 L; Hedetech, Dalian, China) five times every 10 min over a 40 min period using a hand-driven pump (ICQS-1; Beijing Municipal Institute of Labour Protection, Beijing, China). The gas samples were transported within 2-3 days after sampling to the State Key Laboratory of Urban and Regional Ecology (Beijing, China) for analysis using a gas chromatograph (Agilent 6820; Agilent Technologies, Santa Clara, USA) equipped with a flame ionization detector (FID) and separated with a Teflon column $(2 \mathrm{~m} \times 3 \mathrm{~mm})$ packed with TDX-01(60/80 mesh). The oven, injector, and detector temperatures were $80^{\circ} \mathrm{C}, 150^{\circ} \mathrm{C}$, and $300^{\circ} \mathrm{C}$, respectively. The flow rate of the carrier gas $\left(\mathrm{N}_{2}\right)$ was $30 \mathrm{~mL}$ $\mathrm{min}^{-1}$, and the flow rate of $\mathrm{H}_{2}$ and compressed air were set to 20 and $30 \mathrm{~mL} \mathrm{~min}^{-1}$, respectively. Standard $\mathrm{CH}_{4}$ gas (10.2 ppm in air; provided by China $\mathrm{CH}_{4}$ National Research Center for Certified Reference Materials, Beijing) was used to quantify the $\mathrm{CH}_{4}$ concentration in one of every 10 samples, which kept the coefficient of variation of the $\mathrm{CH}_{4}$ concentration in the replicated samples below $1 \%$.

[11] We separated the diffusive and bubble emissions based on the change of $\mathrm{CH}_{4}$ concentration in the chambers. The $\mathrm{CH}_{4}$ emission was considered diffusive if the linear correlation between the $\mathrm{CH}_{4}$ concentration in the chamber and the elapsed time had $\mathrm{r}^{2}$ greater than 0.90 [Marani and Alvalá, 2007]. If the $\mathrm{CH}_{4}$ concentration was punctuated by one or more abrupt increases and the initial concentration in the chambers (at time $\mathrm{t}=0$ ) was close to the ambient air concentration, the abrupt increases were most easily explained by interception of rising gas bubbles by the chamber [Keller and Stallard, 1994]. The diffusive $\mathrm{CH}_{4}$ emission $\left(F_{d} ; \mathrm{mg} \mathrm{CH}_{4} \mathrm{~m}^{-2} \mathrm{~h}^{-1}\right)$ was determined using

$$
F_{d}=\rho \times \mathrm{d} c / \mathrm{d} t \times 273.15 /(273.15+T) \times H
$$

where $\rho$ is the density of $\mathrm{CH}_{4}$ under standard conditions $\left(0.714 \mathrm{~kg} \mathrm{~m}^{-3}\right), \mathrm{d} c / \mathrm{d} t$ is the slope of the linear regression of 
the $\mathrm{CH}_{4}$ concentration in the chamber versus time, $H$ is the height of the chamber above the water or soil surface $(0.3 \mathrm{~m}$ for dry lands and $0.75 \mathrm{~m}$ for rice paddies), and $T$ is the air temperature $\left({ }^{\circ} \mathrm{C}\right)$.

[12] The bubble $\mathrm{CH}_{4}$ emission $\left(F_{b} ; \mathrm{mg} \mathrm{CH}_{4} \mathrm{~m}^{-2} \mathrm{~h}^{-1}\right)$ was determined using

$$
F_{b}=\rho \times \Delta \mathrm{C} / \Delta \mathrm{T} \times 273.15 /(273.15+T) \times H
$$

where $\Delta C$ is the gas concentration difference between the beginning and the end of the enclosure time in the chamber (ppm) and $\Delta T$ is the total time of emplacement (h).

[13] Cropland, deforested land, and fallow land were selected along one side of the Yangtze River at each site (Figure 1 and Table 1). The rice paddy plot was located at $4 \mathrm{~km}$ upstream of Yunyang (Figure 1). In each sampling plot, all measurements were conducted at the same places during all seasons, regardless of inundation or drainage. $\mathrm{CH}_{4}$ emissions were measured once or twice per month in the morning, weather depending, for 15 months (November 2009 to January 2011) in the fallow lands, croplands, deforested lands, and rice paddies at each growing stage and twice per month after the harvest. 17-21 times measurement was carried out at each land use of dry lands and 11 times at the rice paddy plot. $\mathrm{CH}_{4}$ emissions were measured from 8:00-18:00 at $2 \mathrm{~h}$ intervals about once every two months in the fallow land, cropland and deforested land in Zigui in order to assess the variability in $\mathrm{CH}_{4}$ emission during the daytime.

\subsection{Environmental Variables}

[14] During the inundated season, the following parameters were measured in situ: (1) velocity, using LS1206B, Midwest Group, Beijing, China; (2) pH, using HI 8424, Microcomputer HANNA, Rome, Italy; and (3) turbidity, using HI93703, Microcomputer HANNA. Air temperature, water temperature, and water depth were also measured in the field using alcohol thermometers and sounding ropes, respectively. In addition, water samples were collected once every month using plastic bottles $(0.5 \mathrm{~L})$ at a depth of $0.5 \mathrm{~m}$ and kept in a refrigerator at $4{ }^{\circ} \mathrm{C}$ until laboratory analyses could be performed. Water quality parameters, including nitrate nitrogen $\left(\mathrm{NO}_{3}^{-}-\mathrm{N}\right)$, ammonium nitrogen $\left(\mathrm{NH}_{4}^{+}-\mathrm{N}\right)$, total nitrogen (TN), and total phosphorus (TP), were measured according to the methods of the State Environmental Protection Administration of China [Qi et al., 2002]. $\mathrm{NO}_{3}^{-}-\mathrm{N}$ was determined by the spectrophotometric method with phenol disulfonic acid, and $\mathrm{NH}_{4}^{+}-\mathrm{N}$ was determined by Nessler's reagent spectrophotometric method [Qi et al., 2002]. TN and TP were analyzed by peroxodisulfate oxidation of the original water samples. Total organic carbon (TOC) and total inorganic carbon (TIC) were detected using a total organic carbon analyzer (Liquic TOC; Elementar Co., Hanau, Germany). In the drained season, soil temperature was measured in the field using a waterproof thermometer (AD-5604; A\&D Co., Tokyo, Japan) at a depth of $5 \mathrm{~cm}$. Soil samples were collected once every month from a depth of $0-20 \mathrm{~cm}$ for laboratory analysis. Soil $\mathrm{pH}$ and organic carbon and total nitrogen levels were measured using a $\mathrm{pH}$ meter (Delta $320 \mathrm{pH}$ meter; Mettler-Toledo Instruments Ltd., Shanghai, China) and elemental analyzer (Vario EL III; Elementar Co.), respectively.

\subsection{Estimation of Total $\mathrm{CH}_{4}$ Emissions From the Drawdown Area}

[15] To estimate the total $\mathrm{CH}_{4}$ emissions from the TGR drawdown area, two kinds of land (rice paddy and dryland, which included fallow land, cropland, and deforested land) and two periods (inundated and drained seasons) were studied. For each type of land use, the annual $\mathrm{CH}_{4}$ emission was calculated as the summation of the products of the $\mathrm{CH}_{4}$ emission rate, areas, and lengths of the inundated and drained season (equation (3)). Most of rice paddies were located in upland above the elevation of $170 \mathrm{~m}$ and inundated for 214 days with less variation (about 137 days as rice paddies in anaerobic condition, and 77 days as submerged drawdown areas). So the $\mathrm{CH}_{4}$ emission from all rice paddies was estimated with a constant inundation period. The total $\mathrm{CH}_{4}$ emission (TE) in the drawdown area was estimated by summing dryland and rice paddy emissions (equation (3)):

$$
\begin{aligned}
T E= & \sum_{i=145}^{i=175}\left[P_{i} \times F E_{i n}+\left(365-P_{i}\right) \times F E_{d r}\right] \times A_{i} \\
& +\left[P^{\prime} \times F E_{i n}^{\prime}+\left(365-P^{\prime}\right) \times F E_{d r}^{\prime}\right] \times A_{0}
\end{aligned}
$$

where $i$ is the elevation; $P_{i}$ is the inundated duration (days) for dryland at each elevation; $F E_{i n}$ and $F E_{d r}$ are the $\mathrm{CH}_{4}$ emission rates of dryland during the inundated and drained seasons, respectively; $A_{i}$ is the area of dryland at each elevation (range: $145-175 \mathrm{~m}$ ) that was calculated from digital elevation model (DEM) data of the TGR drawdown area using ArcGIS 9.3 (ESRI Co., Redlands, USA); $P^{\prime}$ is the inundated duration of the rice paddy; $F E_{i n}^{\prime}$ and $F E_{d r}^{\prime}$ are the $\mathrm{CH}_{4}$ emission rates of the rice paddy during the inundated and drained seasons, respectively; and $A_{0}$ is the total area of rice paddy, which accounted for $11 \%$ of the drawdown area [Ye et al., 2006].

\subsection{Statistical Analysis}

[16] One-way analysis of variance (ANOVA), in combination with the Tukey test, was used to analyze differences in soil $\mathrm{pH}$, organic carbon, and total nitrogen levels between different land uses at the same site. The normal distribution of the $\mathrm{CH}_{4}$ emissions during the inundated and the drained seasons were tested using Kolmogorov-Smirnov Test. The skewed $\mathrm{CH}_{4}$ emissions distributions required the data set to be normalized by natural logarithmic transformation, and then differences between sites and land uses were tested using ANOVA. Two-way ANOVA was used to test interactions between sites and land uses in terms of $\mathrm{CH}_{4}$ emission during the inundated season. $\mathrm{CH}_{4}$ emissions were linearly regressed in terms of soil temperature at a depth of $5 \mathrm{~cm}$, air-water temperature difference, air temperature, $\mathrm{NH}_{4}^{+}-\mathrm{N}$ content and water depth. A multiple regression model was used to determine the key environmental variables that influenced $\mathrm{CH}_{4}$ emission during the inundated season. Data were analyzed with the SPSS 16.0 statistical package.

\section{Results}

\subsection{Water Level and Inundation Period}

[17] The water level steadily decreased from a high of $171 \mathrm{~m}$ above sea level that was measured on 11 November 


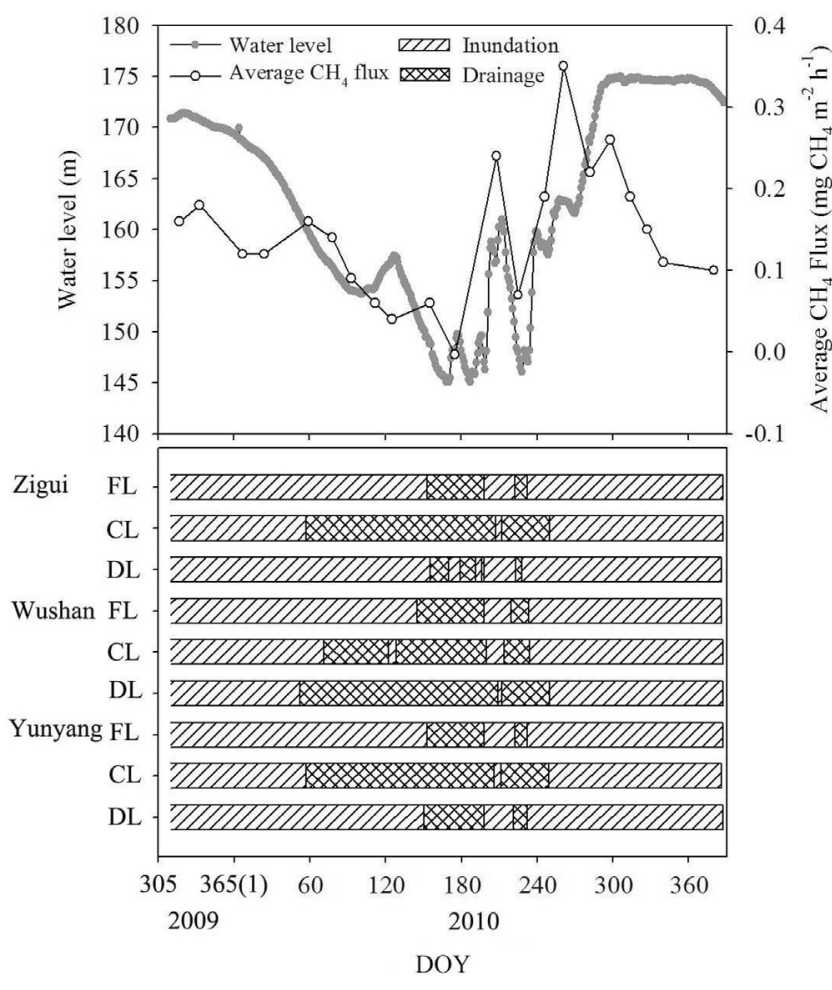

Figure 2. Seasonal variations in water levels, average $\mathrm{CH}_{4}$ emission during the measured periods, and the duration of inundated or drained seasons in nine plots of dry lands. (top) The gray line with solid circles indicates the water level (left axis), and the solid line with open circles indicates the average $\mathrm{CH}_{4}$ emission from all measurements in the dry lands together (right axis). (bottom) The abbreviations (FL, CL, DL) in the left axis are the same as in Figure 1.

2009 (DOY315, 2009) when the study began (Figure 2). On 21 April 2010 (DOY111, 2010), the water level rose because of spring floods. From 9 May (DOY129, 2010), the water level was decreased to $145 \mathrm{~m}$ in order to control flooding (Figure 2). Two floods in the summer of 2010 caused short pulses in the water level on 19 July (DOY200, 2010) and 24 August (DOY236, 2010). On 29 August (DOY241, 2010), the water level began to rise until the target level of $175 \mathrm{~m}$ was achieved on 26 October (DOY299, 2010) (Figure 2).

[18] The inundated period for each plot varied according to its elevation and water level. All of the plots in the drawdown area were drained from 5 June (DOY156, 2010) through 22 August (DOY234, 2010), except for the short inundated period that were caused by floods (Figure 2). The croplands were inundated for less than 229 days above an elevation of $157 \mathrm{~m}$ in order to guarantee that the crops would ripen (Table 1).

\subsection{Soil pH, Carbon, and Nitrogen During the Drainage Season}

[19] The average soil $\mathrm{pH}$ in Zigui was 6.42, which was significantly lower than the $\mathrm{pH}$ of Wushan and Yunyang (8.13 and 8.39, respectively) (Table 1).The mean soil organic carbon content in Zigui was $11.11 \mathrm{~g} \mathrm{~kg}^{-1}$, which was similar to Wushan $\left(10.71 \mathrm{~g} \mathrm{~kg}^{-1}\right)$ but more than twice as high as Yunyang (3.63 $\left.\mathrm{g} \mathrm{kg}^{-1}\right)$ (Table 1). The mean total nitrogen content in Zigui was $0.81 \mathrm{~g} \mathrm{~kg}^{-1}$, which was significantly lower than that of Wushan $\left(1.17 \mathrm{~g} \mathrm{~kg}^{-1}\right)$ but significantly higher than that of Yunyang $\left(0.46 \mathrm{~g} \mathrm{~kg}^{-1}\right)$ (Table 1$)$.

[20] There were no significant differences in terms of soil $\mathrm{pH}$ among the different land uses at the same sites. For organic carbon and total nitrogen, there were no significant differences among the three types of lands used in Zigui, but organic carbon and total nitrogen levels were significantly lower in the fallow land of Wushan and the cropland of Yunyang compared with the other types of lands in Wushan and Yunyang, respectively (Table 1). Organic carbon and total nitrogen levels in the rice paddies were significantly higher than the levels measured in the other types of land studies in Yunyang (Table 1).

\subsection{Water Velocity and Water Quality During the Inundated Season}

[21] There were significant difference in terms of water velocity at all three sites, with the highest measured in Wushan $\left(21.3 \mathrm{~cm} \mathrm{~s}^{-1}\right)$ and the lowest in Zigui $\left(5.2 \mathrm{~cm} \mathrm{~s}^{-1}\right)$ (Table 2). Although the average turbidity was lower in Zigui (11.88 NTU) and Wushan (19.11 NTU) compared with Yunyang (33.71 NTU), the difference was not significant (Table 2). TP, TN, $\mathrm{NH}_{4}^{+}-\mathrm{N}, \mathrm{NO}_{3}^{-}-\mathrm{N}, \mathrm{TIC}$, and TOC levels were not significantly different in the water samples collected at all three sites (Table 2).

\subsection{Diffusive $\mathrm{CH}_{4}$ Emissions From Different Land Uses and Sites}

[22] The drawdown area was a source of $\mathrm{CH}_{4}$ during the inundated season, with emissions ranging from 0.10 to $0.37 \mathrm{mg} \mathrm{CH}_{4} \mathrm{~m}^{-2} \mathrm{~h}^{-1}$. The drawdown area acted as a sink or weak source of $\mathrm{CH}_{4}$ during the drained season, with emissions ranging from -0.034 to $0.036 \mathrm{mg} \mathrm{CH}_{4} \mathrm{~m}^{-2} \mathrm{~h}^{-1}$. The rice paddy, however, released $3.94 \mathrm{mg} \mathrm{CH}_{4} \mathrm{~m}^{-2} \mathrm{~h}^{-1}$ during the drained season (Table 3). No significant differences were present in terms of $\mathrm{CH}_{4}$ emission during the drained or the inundated seasons among the various land

Table 2. Water Velocity and Water Quality During the Inundated Season at the Zigui, Wushan, and Yunyang Sites of the Drawdown Area of the Three Gorges Reservoir ${ }^{\mathrm{a}}$

\begin{tabular}{|c|c|c|c|c|c|c|c|c|}
\hline Sites & $\mathrm{V}_{\text {water }}\left(\mathrm{cm} \mathrm{s}^{-1}\right)$ & $\begin{array}{l}\text { Turbidity } \\
\text { (NTU) }\end{array}$ & $\begin{array}{l}\text { Total Phosphorus } \\
\quad\left(\mathrm{mg} \mathrm{L}^{-1}\right)\end{array}$ & $\begin{array}{l}\text { Total Nitrogen } \\
\quad\left(\mathrm{mg} \mathrm{L}^{-1}\right)\end{array}$ & $\begin{array}{l}\mathrm{NH}_{4}^{+}-\mathrm{N} \\
\left(\mathrm{mg} \mathrm{L}^{-1}\right)\end{array}$ & $\begin{array}{l}\mathrm{NO}_{3}^{-}-\mathrm{N} \\
\left(\mathrm{mg} \mathrm{L}^{-1}\right)\end{array}$ & $\begin{array}{l}\text { Total Inorganic } \\
\text { Carbon }\left(\mathrm{mg} \mathrm{L}^{-1}\right)\end{array}$ & $\begin{array}{c}\text { Total Organic } \\
\text { Carbon }\left(\mathrm{mg} \mathrm{L}^{-1}\right)\end{array}$ \\
\hline & & & & & & & & \\
\hline Wushan & $21.3 \pm 14.6$ & $19.11 \pm 49.34$ & $0.09 \pm$ & $8 \pm$ & $0.08 \pm$ & $1.11 \pm$ & $25.56=$ & $2.00 \pm 1.09$ \\
\hline Yunyang & $12.6 \pm 8.5$ & $33.71 \pm 92.97$ & $0.11 \pm 0.04$ & $1.58 \pm 0.49$ & $0.16 \pm 0.13$ & $1.26 \pm 0.26$ & $24.45 \pm 3.05$ & $1.68 \pm 0.95$ \\
\hline
\end{tabular}

${ }^{\mathrm{a}}$ Values are the mean $\pm \mathrm{SE}$ (standard error). 
Table 3. Average Diffusive $\mathrm{CH}_{4}$ Emissions of Different Land Types During the Drained and Inundated Seasons and the Entire Field Study $\left(\mathrm{mg} \mathrm{CH} \mathrm{CH}^{-2} \mathrm{~h}^{-1}\right)^{\mathrm{a}}$

\begin{tabular}{|c|c|c|c|c|c|c|c|c|c|c|}
\hline \multirow[b]{2}{*}{ Land Use } & \multirow[b]{2}{*}{ Site } & \multicolumn{3}{|c|}{ Drainage } & \multicolumn{3}{|c|}{ Inundation } & \multicolumn{3}{|c|}{ Entire Study } \\
\hline & & $\mathrm{n}$ & Mean & SE & $\mathrm{n}$ & Mean & SE & $\mathrm{n}$ & Mean & SE \\
\hline \multirow[t]{4}{*}{ Fallow land } & Zigui & 2 & $-0.027^{(a)}$ & 0.089 & 16 & $0.15^{\text {(a) }}$ & 0.12 & 18 & $0.13^{(\mathrm{a})}$ & 0.13 \\
\hline & Wushan & 3 & $-0.034^{(a)}$ & 0.019 & 14 & $0.31^{(\mathrm{b})}$ & 0.47 & 17 & $0.25^{(\mathrm{a})}$ & 0.44 \\
\hline & Yunyang & 3 & $0.014^{(\mathrm{a})}$ & 0.044 & 14 & $0.22^{(\mathrm{b})}$ & 0.14 & 17 & $0.19^{(\mathrm{a})}$ & 0.15 \\
\hline & Average & 8 & -0.015 & 0.053 & 44 & 0.22 & 0.29 & 52 & 0.19 & 0.28 \\
\hline \multirow[t]{4}{*}{ Cropland } & Zigui & 9 & $-0.011^{(\mathrm{a})}$ & 0.024 & 9 & $0.10^{(\mathrm{a})}$ & 0.09 & 18 & $0.05^{(\mathrm{b})}$ & 0.08 \\
\hline & Wushan & 7 & $-0.017^{(\mathrm{a})}$ & 0.024 & 10 & $0.21^{(\mathrm{b})}$ & 0.15 & 17 & $0.12^{(\mathrm{a}, \mathrm{b})}$ & 0.16 \\
\hline & Yunyang & 9 & $0.007^{(\mathrm{a})}$ & 0.041 & 8 & $0.37^{(\mathrm{b})}$ & 0.39 & 17 & $0.20^{(\mathrm{b})}$ & 0.34 \\
\hline & Average & 25 & $-0.007^{(\mathrm{a})}$ & 0.031 & 27 & 0.22 & 0.26 & 52 & 0.12 & 0.22 \\
\hline \multirow[t]{4}{*}{ Deforested land } & Zigui $^{\circ}$ & 2 & $-0.002^{(a)}$ & 0.043 & 16 & $0.14^{(\mathrm{a})}$ & 0.19 & 18 & $0.13^{(\mathrm{a})}$ & 0.19 \\
\hline & Wushan & 10 & $-0.013^{(\mathrm{a})}$ & 0.024 & 7 & $0.19^{(\mathrm{b})}$ & 0.14 & 17 & $0.08^{(\mathrm{b})}$ & 0.14 \\
\hline & Yunyang & 1 & $0.036^{(a)}$ & 0.007 & 15 & $0.30^{(\mathrm{b})}$ & 0.23 & 16 & $0.28^{(\mathrm{c})}$ & 0.24 \\
\hline & Average & 13 & -0.007 & 0.030 & 38 & 0.21 & 0.21 & 51 & 0.18 & 0.24 \\
\hline \multirow[t]{3}{*}{ Average $^{\mathrm{b}}$} & Zigui & 13 & $-0.012^{(a)}$ & 0.040 & 41 & $0.14^{(\mathrm{a})}$ & 0.15 & 54 & $0.10^{(\mathrm{a})}$ & 0.15 \\
\hline & Wushan & 20 & $-0.018^{(\mathrm{a})}$ & 0.024 & 31 & $0.25^{(\mathrm{b})}$ & 0.33 & 51 & $0.15^{(\mathrm{b})}$ & 0.29 \\
\hline & Yunyang & 13 & $0.011^{(a)}$ & 0.040 & 37 & $0.28^{(\mathrm{b})}$ & 0.25 & 50 & $0.24^{(\mathrm{c})}$ & 0.27 \\
\hline Total average ${ }^{c}$ & & 46 & -0.008 & 0.035 & 109 & 0.22 & 0.26 & 155 & 0.16 & 0.24 \\
\hline Rice paddy & Yunyang & 7 & 3.94 & 4.22 & 4 & 0.3 & 0.26 & 11 & 2.61 & 3.76 \\
\hline
\end{tabular}

${ }^{a}$ The letters $(a),(b)$, and $(c)$ indicate significant difference $(p<0.05)$ for each land use or average values at each site. Abbreviations: $n$, number of samples; $\mathrm{SE}$, standard error.

${ }^{\mathrm{b}}$ Average $\mathrm{CH}_{4}$ emission of the fallow land, cropland, and deforested land at each site.

${ }^{\mathrm{c}}$ Total average $\mathrm{CH}_{4}$ emission of the fallow lands, croplands, and deforested lands at Zigui, Wushan, and Yunyang.

uses at the same sites, except the rice paddy (Table 3). Although there were no significant differences in $\mathrm{CH}_{4}$ emission between sites during the drained season, $\mathrm{CH}_{4}$ emissions in Wushan and Yunyang were significantly higher than those in Zigui for the same fallow lands, croplands, and deforested lands during the inundated season (Table 3 ).

[23] The annual average $\mathrm{CH}_{4}$ emission from the croplands (0.12 $\mathrm{mg} \mathrm{CH}_{4} \mathrm{~m}^{-2} \mathrm{~h}^{-1}$ ) was significantly lower than that of the fallows lands $\left(0.19 \mathrm{mg} \mathrm{CH}_{4} \mathrm{~m}^{-2} \mathrm{~h}^{-1}\right)$ and the deforested lands $\left(0.18 \mathrm{mg} \mathrm{CH}_{4} \mathrm{~m}^{-2} \mathrm{~h}^{-1}\right)$ (Table 3). The average $\mathrm{CH}_{4}$ emission across the entire sampled season was $2.61 \mathrm{mg} \mathrm{CH}_{4}$ $\mathrm{m}^{-2} \mathrm{~h}^{-1}$ in the rice paddy (Table 3), which was the highest among the four types of land that were examined. The average $\mathrm{CH}_{4}$ emission was the highest at Yunyang $(0.24 \mathrm{mg}$ $\left.\mathrm{CH}_{4} \mathrm{~m}^{-2} \mathrm{~h}^{-1}\right)$, followed by Wushan $\left(0.15 \mathrm{mg} \mathrm{CH}_{4} \mathrm{~m}^{-2}\right.$ $\left.\mathrm{h}^{-1}\right)$ and Zigui $\left(0.10 \mathrm{mg} \mathrm{CH}_{4} \mathrm{~m}^{-2} \mathrm{~h}^{-1}\right)$ (Table 3). There was a significant interaction between sites and land uses in terms of $\mathrm{CH}_{4}$ emissions during the inundated season.

\subsection{Bubble $\mathrm{CH}_{4}$ Emission From the Drawdown Area}

[24] During the inundated season, bubbles were observed 10 times in all the measurements, with a frequency of bubbles occurrence of $2.9 \%$ in the TGR drawdown area (Figure 3 ). The average bubble emission was $2.36 \pm 2.15 \mathrm{mg} \mathrm{CH}_{4} \mathrm{~m}^{-2}$ $\mathrm{h}^{-1}$ when bubbles occurred, but the average bubble emission was $0.068 \mathrm{mg} \mathrm{CH}_{4} \mathrm{~m}^{-2} \mathrm{~h}^{-1}$ during the inundated season in consideration of the frequency of bubbles.

\subsection{Variations in $\mathrm{CH}_{4}$ Emission During the Daytime}

[25] $\mathrm{CH}_{4}$ emissions began to increase from 6:00 or 8:00 and reached maximum values at 12:00 or 14:00, then gradually decreased thereafter (Figure 4). The variations in $\mathrm{CH}_{4}$ emission during the daytime were small on most days, except in fallow lands on 11 March, croplands on 20 October, and deforested lands on 10 August and 30 May (Figure 4). In addition, the variations in $\mathrm{CH}_{4}$ emission during the daytime in croplands were less than those measured in fallow and deforested lands (Figure 4). Such $2 \mathrm{~h}$ measurement was not conducted at the rice paddy plot during the daytime.

\subsection{Environmental Variables Influencing $\mathrm{CH}_{4}$ Emission}

[26] There were significant relationships between $\mathrm{CH}_{4}$ emission and water depth, air temperature, air-water temperature difference, and $\mathrm{NH}_{4}^{+}-\mathrm{N}$ content during the inundated season and, additionally, soil temperature at a depth of $5 \mathrm{~cm}$ during the drained season (Figure 5). The results of the multiple regression analysis show that $\mathrm{CH}_{4}$ emission $(F)$ is significantly related to the air-water temperature difference

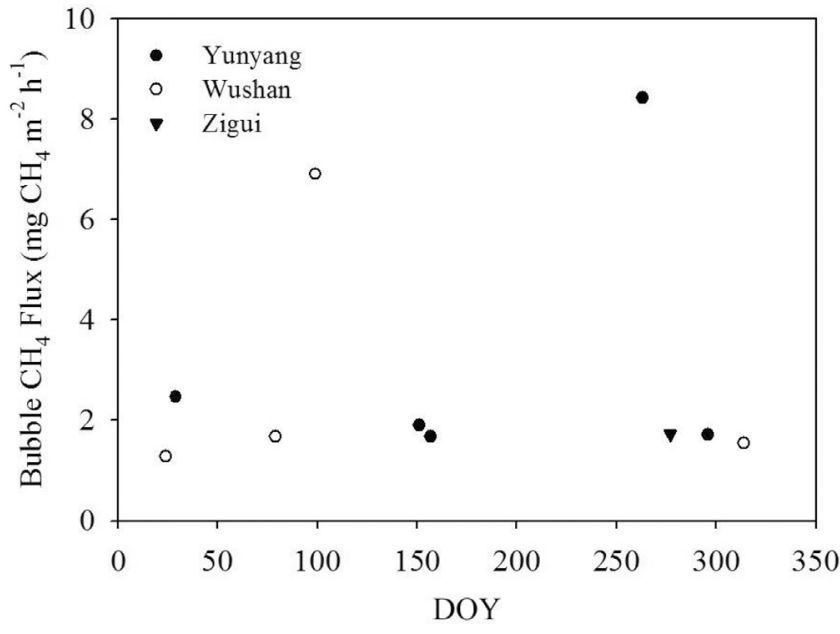

Figure 3. Bubble $\mathrm{CH}_{4}$ flux and its distribution in Yunyang, Wushan, and Zigui in 2010. 

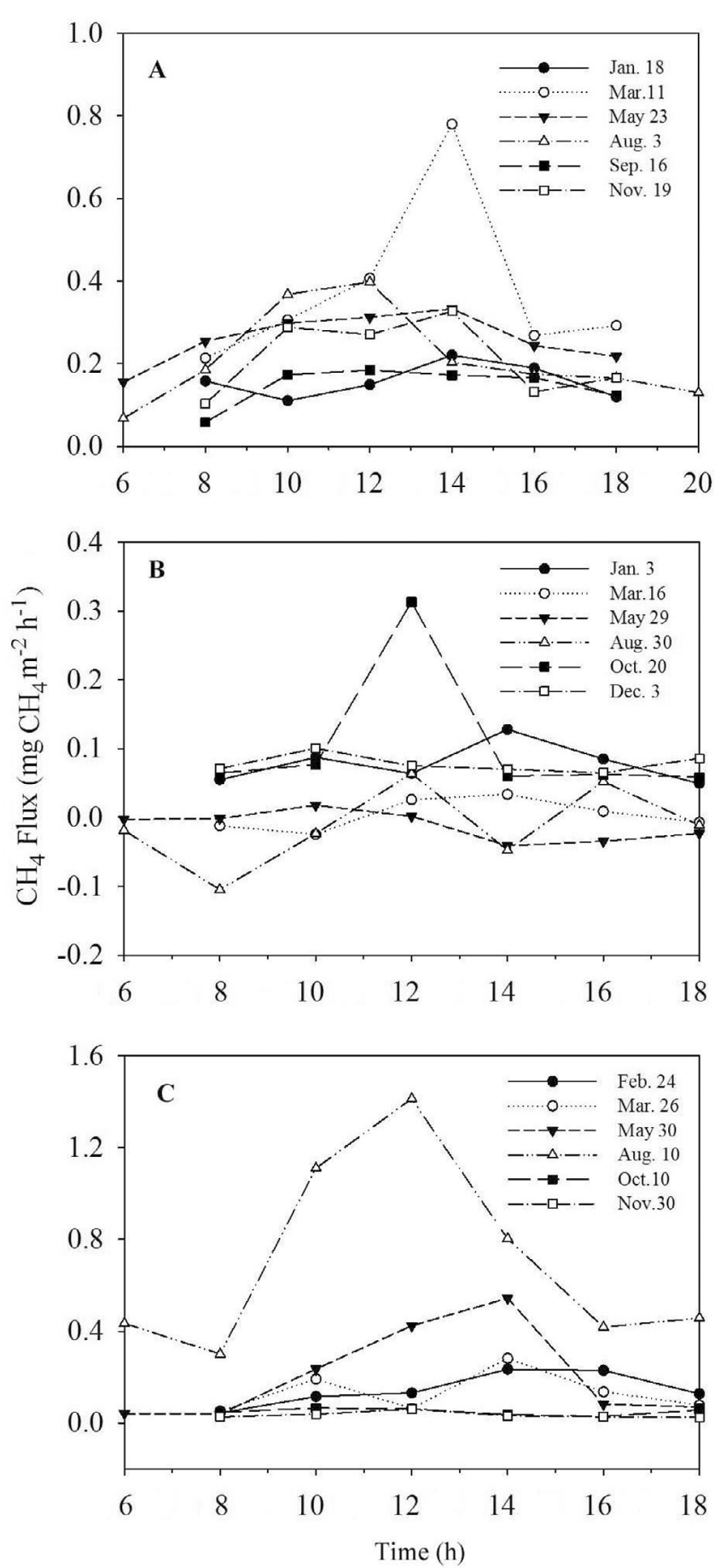

Figure 4. The variations in $\mathrm{CH}_{4}$ emission during the daytime at (a) fallow land, (b) cropland, and (c) deforested land in Zigui.

$(T)$, water depth $(D)$, and air temperature $\left(T_{\text {air }}\right)$, as shown by equation (4):

$$
F=0.122+0.013 T-0.003 D+0.008 T_{\text {air }}
$$

\subsection{Total $\mathrm{CH}_{4}$ Emission From the Drawdown Area of TGR}

[27] In dryland, diffusive $\mathrm{CH}_{4}$ emission was estimated to be 233.9-490.3 $\mathrm{Mg} \mathrm{CH}_{4} \mathrm{yr}^{-1}$ during the inundated season and -22.4-21.6 $\mathrm{Mg} \mathrm{CH}_{4} \mathrm{yr}^{-1}$ during the drained season. Therefore, the annual diffusive $\mathrm{CH}_{4}$ emission was 211.5 $511.9 \mathrm{Mg} \mathrm{CH}_{4} \mathrm{yr}^{-1}$ in dry lands in the TGR drawdown area (Table 4). $\mathrm{CH}_{4}$ emission from rice paddies was estimated to be about $676.6 \mathrm{Mg} \mathrm{CH} \mathrm{yr}^{-1}$ (Table 4). In addition, $145.4 \mathrm{Mg} \mathrm{CH} 4 \mathrm{yr}^{-1}$ was estimated from the drawdown area by bubbles (Table 4). Therefore, the total estimated $\mathrm{CH}_{4}$ emission from the TGR drawdown area was 1033.51333.9 $\mathrm{Mg} \mathrm{CH}_{4} \mathrm{yr}^{-1}$, which accounts for $42-54 \%$ of the $\mathrm{CH}_{4}$ emission from the water surface $\left(2.46 \mathrm{Gg} \mathrm{CH}_{4} \mathrm{yr}^{-1}\right)$ [Chen et al., 2011].

\section{Discussion}

\subsection{Contribution of the Drawdown Area to $\mathrm{CH}_{4}$ Emission in TGR}

[28] Although hydropower, as a renewable source of energy, is considered an important way to mitigate global warming by replacing fossil fuel combustion for the generation of electricity, $\mathrm{CH}_{4}$ emissions from man-made hydropower reservoirs cause doubts regarding its mitigation potential when compared with traditional forms of fossil fuel energy [Cullenward and Victor, 2006]. Based on our monthly to semimonthly measurement on $\mathrm{CH}_{4}$ emissions from four types of land at three sites in the drawdown area along the mainstream of TGR, the annual average $\mathrm{CH}_{4}$ emission was $0.23 \mathrm{mg} \mathrm{CH}_{4} \mathrm{~m}^{-2} \mathrm{~h}^{-1}\left(0.16 \mathrm{mg} \mathrm{CH} \mathrm{m}^{-2} \mathrm{~h}^{-1}\right.$ of diffusive flux plus $0.068 \mathrm{mg} \mathrm{CH} \mathrm{Cm}^{-2} \mathrm{~h}^{-1}$ of bubble flux) in the drawdown area of TGR in 2010 (Table 3), which is less than that reported by Chen et al. [2009] $\left(6.7 \mathrm{mg} \mathrm{CH}_{4} \mathrm{~m}^{-2} \mathrm{~h}^{-1}\right)$, Chen et al. [2011] $\left(0.29 \mathrm{mg} \mathrm{CH}_{4} \mathrm{~m}^{-2} \mathrm{~h}^{-1}\right)$, and Lu et al. [2011] $\left(0.34 \mathrm{mg} \mathrm{CH} \mathrm{m}^{-2} \mathrm{~h}^{-1}\right)$. Since the emission accounts for up to a half of the total emissions from the water surface, the drawdown areas of this reservoir should not be neglected when assessing emissions from hydropower reservoirs by potentially others.

\subsection{Effect of Land Use on $\mathrm{CH}_{4}$ Emission}

[29] The annual average $\mathrm{CH}_{4}$ emissions from croplands were smaller than those of the fallow and deforested lands most likely because the croplands were at higher elevation and inundated for a shorter period of time, which had a relatively short duration of anoxia. The annual average $\mathrm{CH}_{4}$ emissions from croplands, deforested lands, and fallow lands were positively related with their average durations of inundation (data not shown). Land use did not impact $\mathrm{CH}_{4}$ emissions at the same site during any season, except for rice paddies. Rice paddies, as a parcel of land that is waterlogged during the drained season, are a significant source of $\mathrm{CH}_{4}$ (Table 3). $\mathrm{CH}_{4}$ emissions from rice paddies have been measured for a long time in China because of their significant contribution to national $\mathrm{CH}_{4}$ emissions [Zhuang et al., 2009]. The average $\mathrm{CH}_{4}$ emission of Chinese rice paddies has been reported to be about $8.4 \mathrm{mg} \mathrm{CH}_{4} \mathrm{~m}^{-2} \mathrm{~h}^{-1}$ [Lu et al., 2010]. In this study, the average $\mathrm{CH}_{4}$ emission during the growing stage was $5.85 \mathrm{mg} \mathrm{CH} \mathrm{m}^{-2} \mathrm{~h}^{-1}$.

\subsection{Spatiotemporal Variations in $\mathrm{CH}_{4}$ Emission}

[30] Seasonal variations in the water level affect the anaerobic conditions that ultimately determine $\mathrm{CH}_{4}$ emission. From June to August, the decline in the water level 

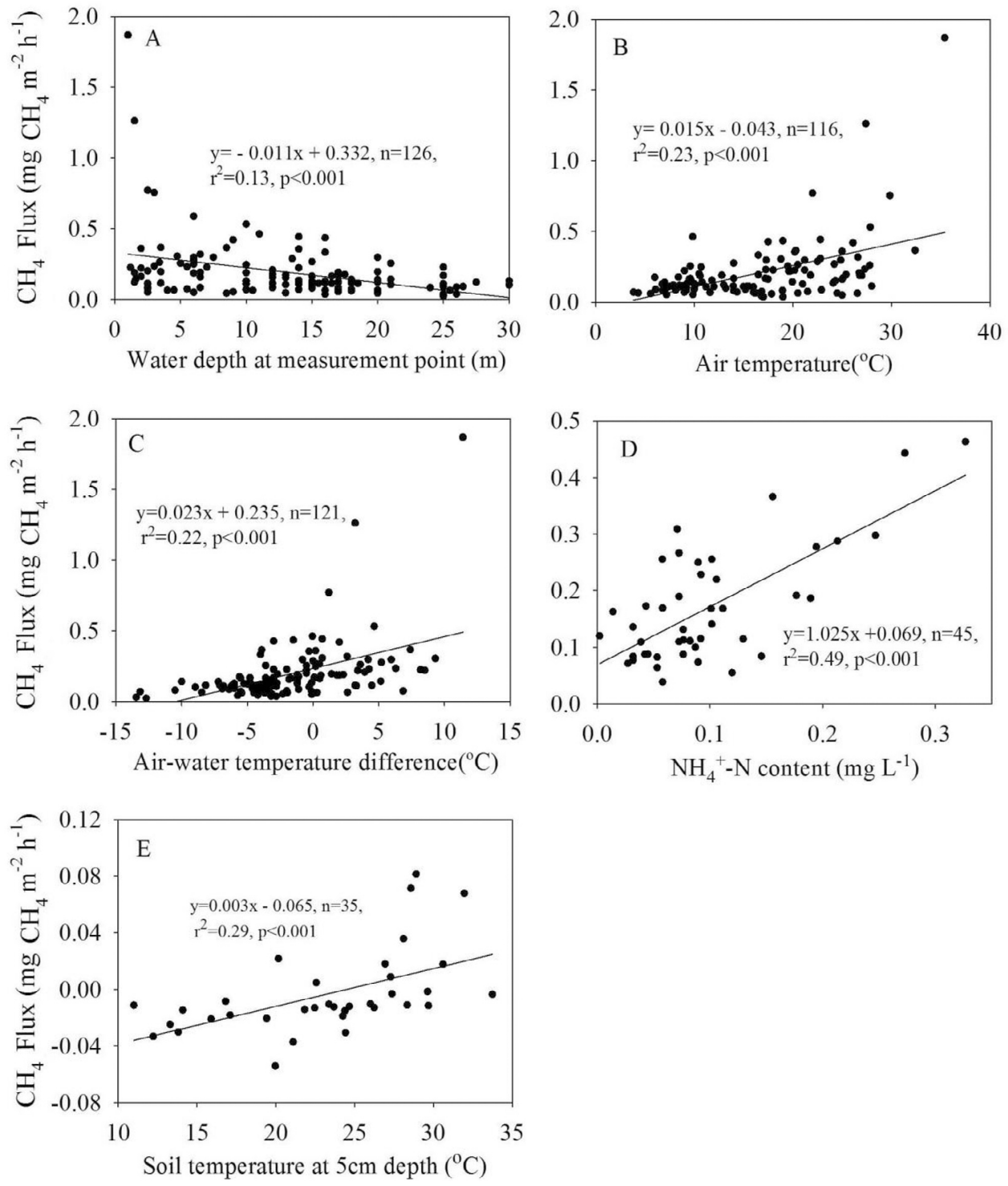

Figure 5. Relationships between $\mathrm{CH}_{4}$ emissions in the seasonal variation and (a) water depth at the measurement point, (b) air temperature, (c) air-water temperature difference, (d) $\mathrm{NH}_{4}^{+}-\mathrm{N}$ content in the inundated season, and (e) soil temperature at a depth of $5 \mathrm{~cm}$ during the inundated season.

effectively drained all of the measured plots (Figure 2), except the rice paddy. In the drained season, $\mathrm{CH}_{4}$ emissions were weak, or the land acted as a weak sink because of the presence of methanotrophic bacteria under aerobic conditions.
In this study during the drained period, the fallow lands, croplands, and deforested lands in Zigui and Wushan acted as $\mathrm{CH}_{4}$ sinks $\left(-0.012\right.$ and $-0.018 \mathrm{mg} \mathrm{CH}_{4} \mathrm{~m}^{-2} \mathrm{~h}^{-1}$, respectively), while small $\mathrm{CH}_{4}$ emissions were observed in Yunyang

Table 4. Estimation of $\mathrm{CH}_{4}$ Emission Levels From the Drawdown Area of the Three Gorges Reservoir

\begin{tabular}{|c|c|c|c|c|c|c|c|c|c|}
\hline & \multirow[b]{2}{*}{ Types } & \multirow[b]{2}{*}{ Area $\left(\mathrm{km}^{2}\right)$} & \multicolumn{3}{|c|}{ Inundated Season } & \multicolumn{3}{|c|}{ Drained Season } & \multirow[b]{2}{*}{$\begin{array}{c}\text { Total } \mathrm{CH}_{4} \\
\text { Estimation }(\mathrm{Mg})\end{array}$} \\
\hline & & & $\begin{array}{c}\mathrm{CH}_{4} \text { Emission } \\
\left(\mathrm{mg} \mathrm{CH} \mathrm{m}^{-2} \mathrm{~h}^{-1}\right)\end{array}$ & $\begin{array}{l}\text { Duration } \\
\text { (d) }\end{array}$ & $\begin{array}{c}\text { Total } \mathrm{CH}_{4} \\
\text { Emission }(\mathrm{Mg})\end{array}$ & $\begin{array}{c}\mathrm{CH}_{4} \text { Emission } \\
\left(\mathrm{mg} \mathrm{CH}_{4} \mathrm{~m}^{-2} \mathrm{~h}^{-1}\right)\end{array}$ & $\begin{array}{l}\text { Duration } \\
\text { (d) }\end{array}$ & $\begin{array}{c}\text { Total } \mathrm{CH}_{4} \\
\text { Emission }(\mathrm{Mg})\end{array}$ & \\
\hline \multirow[t]{2}{*}{ Diffusion } & Dry land & 400 & $0.14-0.28$ & $198^{\mathrm{b}}$ & $233.9-490.3$ & $-0.01-0.01$ & 167 & $-22.4-21.6$ & $211.5-511.9$ \\
\hline & Rice land & $50^{\mathrm{a}}$ & 0.30 & 77 & 27.4 & $\begin{array}{c}3.94^{\mathrm{c}} \\
0.011^{\mathrm{d}}\end{array}$ & $\begin{array}{l}137 \\
151\end{array}$ & $\begin{array}{c}647.2 \\
2.05\end{array}$ & 676.6 \\
\hline Ebullition & & 450 & 0.068 & $198^{b}$ & 145.4 & 0 & 167 & 0 & 145.4 \\
\hline
\end{tabular}

${ }^{\mathrm{a}}$ From Ye et al. [2006].

${ }^{\mathrm{b}}$ Average inundated duration of the drawdown area at an elevation of 145-175 m.

${ }^{\mathrm{c}}$ Average $\mathrm{CH}_{4}$ emission during the rice growing stage.

${ }^{\mathrm{d}}$ Average $\mathrm{CH}_{4}$ emission after the rice paddy was harvested. 
(0.011 mg CH $\left.\mathrm{CH}_{4}^{-2} \mathrm{~h}^{-1}\right)$. Iqbal et al. [2009] reported that vegetable fields, citrus orchards, and pine forests in Zigui act as $\mathrm{CH}_{4}$ sinks $\left(-0.011 \mathrm{mg} \mathrm{CH}_{4} \mathrm{~m}^{-2} \mathrm{~h}^{-1}\right)$. Compared with other reports on forest soil $\left(-0.038 \mathrm{mg} \mathrm{CH}_{4} \mathrm{~m}^{-2} \mathrm{~h}^{-1}\right)$ in Dinghushan Nature Reserve [Tang et al., 2006] and pine plantation and orchard soils $\left(-0.029 \mathrm{mg} \mathrm{CH}_{4} \mathrm{~m}^{-2} \mathrm{~h}^{-1}\right)$ in Heshan, Guangdong Province [Liu et al., 2008], the low $\mathrm{CH}_{4}$ uptake values in this study may be attributed to a higher soil pH (6.21-8.63 versus 3.9 in Dinghushan and 3.95-5.91 in Heshan), since acidic soil usually leads to a higher rate of $\mathrm{CH}_{4}$ uptake [Sitaula et al., 1995].

[31] When plots were inundated from September through the following February, $\mathrm{CH}_{4}$ was released from the water surface above the fallow lands, croplands, deforested lands, and rice paddies (Figure 2). $\mathrm{CH}_{4}$ emission from the TGR drawdown area was $0.22 \mathrm{mg} \mathrm{CH} \mathrm{m}^{-2} \mathrm{~h}^{-1}$ during the inundated season, higher than that reported for the Ertan reservoir in southwest China $\left(0.117 \mathrm{mg} \mathrm{CH}_{4} \mathrm{~m}^{-2} \mathrm{~h}^{-1}\right)$ [Zheng et al., 2011b] and close to that reported for the Xiangxi tributary of TGR $\left(0.2449 \mathrm{mg} \mathrm{CH}_{4} \mathrm{~m}^{-2} \mathrm{~h}^{-1}\right)$ [Zhao et al., 2011]. In addition, our results are comparable to those reported for the boreal region of Canada, including the Laforge-1 $\left(0.21 \mathrm{mg} \mathrm{CH} \mathrm{m}^{-2} \mathrm{~h}^{-1}\right)$ and La Grande-2 $\left(0.58 \mathrm{mg} \mathrm{CH}_{4} \mathrm{~m}^{-2} \mathrm{~h}^{-1}\right)$ [Duchemin et al., 1995] and 55 reservoirs nationwide distribution in Canada $(0.37 \pm 0.5 \mathrm{mg}$ $\mathrm{CH}_{4} \mathrm{~m}^{-2} \mathrm{~h}^{-1}$ ) [Tremblay et al., 2005]. However, our results are remarkably lower than those reported for tropical reservoirs in Brazil $\left(3.27 \pm 2.75 \mathrm{mg} \mathrm{CH}_{4} \mathrm{~m}^{-2} \mathrm{~h}^{-1}\right)$ [dos Santos et al., 2006] and Petit Saut Reservoir in French Guiana $\left(1.93 \pm 1.20 \mathrm{mg} \mathrm{CH} \mathrm{m}^{-2} \mathrm{~h}^{-1}\right)$ [Abril et al., 2005]. Barros et al. [2011] found that $\mathrm{CH}_{4}$ emissions exponentially decline with increasing latitude, as the warm and anoxic conditions conducive to methanogenesis are less present in higher latitudes. This partly explains why TGR $\left(29^{\circ} 16^{\prime}-31^{\circ} 25^{\prime} \mathrm{N}\right)$ does not emit as much $\mathrm{CH}_{4}$ as tropical reservoirs. In addition, tropical reservoirs that were created by flooding uncleared tropical forests, such as Balbina in Brazil or Petit Saut Reservoir in French Guiana, are rich in organic carbon and able to contribute significantly more $\mathrm{CH}_{4}$ emissions. Intensive clearing before the impoundment of TGR did not provide much organic substrate for $\mathrm{CH}_{4}$ production.

[32] Water velocity and turbulence were important factors that contributed to the annual average $\mathrm{CH}_{4}$ emissions being highest upstream in Yunyang and decreasing gradually to Wushan and Zigui (Table 3). This spatial difference in $\mathrm{CH}_{4}$ emissions was apparent during the inundated season, but not during the drained season (Table 3), and was thus related to factors specific to water flow. Water velocity is an important source of turbulence at the air-water interface and influences the gas transfer velocity $\left(\mathrm{k}_{600}\right)$, thereby enhancing $\mathrm{CH}_{4}$ emission from water surface [Borges et al., 2004; Ferrón et al., 2007]. Zigui, located 2 km upstream from the Three Gorges Dam, had significantly lower water velocity $\left(5.2 \mathrm{~cm} \mathrm{~s}^{-1}\right)$ than Wushan $(21.3 \mathrm{~cm}$ $\left.\mathrm{s}^{-1}\right)$ and Yunyang $\left(12.6 \mathrm{~cm} \mathrm{~s}^{-1}\right)$ during the inundated season $(\mathrm{p}<0.05)$ (Table 2). In addition, turbidity was higher upstream in Yunyang (33.71 NTU) than downstream in Wushan (19.11 NTU) and Zigui (11.88 NTU) during the inundated season (Table 2), potentially indicating that the greater sediment load upstream provided additional substrate for methanogenesis and thus emissions.

\subsection{Environmental Factors Influencing $\mathrm{CH}_{\mathbf{4}}$ Emission}

[33] Air temperature [Bergström et al., 2007], water temperature [Thérien and Morrison, 2005], and soil temperature [Juutinen et al., 2001] are important factors that influence the microbial activities that produce $\mathrm{CH}_{4}$ under anaerobic conditions. Increased difference of the air and water temperatures $\left(T_{\text {water }}>T_{\text {air }}\right)$ might cause destabilization near the water surface, thereby enhancing the gas transfer velocity by as much as 4-30\% due to evaporation [Guérin et al., 2007]. In this study, $\mathrm{CH}_{4}$ emission was influenced by the air-water temperature difference during the inundated season (Figure 5c), as has been seen elsewhere [Zheng et al., 2011b]. A regression analysis performed on the $2 \mathrm{~h}$ increment measurements at each site (data not shown) also revealed that air-water temperature difference accounted for $42.3 \%$ and $39.4 \%$ of $\mathrm{CH}_{4}$ emission variability at the fallow and deforested lands, respectively. During the drained season of this study, the soil temperature at a depth of $5 \mathrm{~cm}$ was positively correlated with $\mathrm{CH}_{4}$ emission (Figure 5e), which was in agreement with many other field studies [Iqbal et al., 2009; Liu et al., 2008]. Whether a soil was a net source or sink for $\mathrm{CH}_{4}$ depended on the relative rates between methanogenic and methanotrophic activities [Topp and Pattey, 1997], but methanogenic bacteria were much more responsive to temperature than methanotrophic bacteria, and optimum temperatures for both processes were about $25^{\circ} \mathrm{C}$ [Dunfield et al., 1993]. When temperature rose or fell, the $\mathrm{CH}_{4}$ production rate increased or decreased faster than that of $\mathrm{CH}_{4}$ consumption. Therefore, more $\mathrm{CH}_{4}$ was emitted at high temperatures and less $\mathrm{CH}_{4}$ was released at low temperatures.

[34] Due to seasonal fluctuations in the water level, the plots in the drawdown area switched from being a $\mathrm{CH}_{4}$ source $\left(0.10-0.37 \mathrm{mg} \mathrm{CH}_{4} \mathrm{~m}^{-2} \mathrm{~h}^{-1}\right)$ during the inundated season to being a weak source or sink $(-0.034-0.036 \mathrm{mg}$ $\mathrm{CH}_{4} \mathrm{~m}^{-2} \mathrm{~h}^{-1}$ ) during the drained season (Table 3). A similar transformation has been reported in alternating wet and dry zones in riverine zones and wetlands [e.g., Smith et al., 2000] and in a tundra ecosystem with areas of varying water saturation levels [e.g., Merbold et al., 2009]. $\mathrm{CH}_{4}$ is produced in soils as the end product of anaerobic organic matter decomposition [Topp and Pattey, 1997], and as exposed soils contain more oxygen than those overlain by water, higher emissions should happen when the drawdown areas are inundated. The negative relationship between $\mathrm{CH}_{4}$ emission and water depth found in this study and elsewhere [Soumis et al., 2004; Duchemin et al., 1995; Zheng et al., 2011b] is most likely due to the reduction in time for $\mathrm{CH}_{4}$ oxidation to occur with decreasing depths. Thus, more $\mathrm{CH}_{4}$ is able to reach the atmosphere [Juutinen et al., 2001]. Water depth was an important factor influencing hourly emission variations on different sampling days, as exemplified by the largest variation occurring on 11 March in the fallow lands when water depth was the shallowest $(5 \mathrm{~m})$. Methane emissions were also high on 10 August and 30 May in deforested lands partly because of shallow water depths.

\section{Conclusion}

[35] Land uses, especially rice cultivation and its management, are critical contributors to $\mathrm{CH}_{4}$ emission in the drawdown area of TGR. Among the other three land uses studied - fallow land, cropland, and deforested land - there was no significant difference in terms of $\mathrm{CH}_{4}$ emission 
during the drained and inundated seasons. Differences in annual average $\mathrm{CH}_{4}$ emissions are attributed to the periods of time that the measurement plots were inundated. Water level fluctuations were the main environmental factors that influenced $\mathrm{CH}_{4}$ emission. The average $\mathrm{CH}_{4}$ emissions decreased from upstream to downstream plots nearer to the drawdown area, which could be due to differences in water velocities and amounts of deposited sediment. The drawdown area occupies one third or more of the TGR surface area, and the total $\mathrm{CH}_{4}$ emission from the drawdown area is $42-54 \%$ of the total emissions from the reservoir surface. Ultimately, $\mathrm{CH}_{4}$ emissions from the drawdown areas of reservoirs require further study and consideration when assessing total seasonal emissions from such water bodies.

[36] Acknowledgments. This work was supported by the National Natural Science Foundation of China (50809067), Ministry of Science and Technology of the People's Republic of China (2010CB955904-03), and the Strategic Priority Research Program of the Chinese Academy of Sciences (XDA05060102 and XDA05050602). We also acknowledge Yafei Yuan for her suggestions on this article and three anonymous reviewers for their improvements to the paper.

\section{References}

Abril, G., F. Guérin, S. Richard, R. Delmas, C. Galy Lacaux, P. Gosse, A. Tremblay, L. Varfalvy, M. A. dos Santos, and B. Matvienko (2005), Carbon dioxide and methane emissions and the carbon budget of a 10-year old tropical reservoir (Petit Saut, French Guiana), Global Biogeochem. Cycles, 19, GB4007, doi:10.1029/2005GB002457.

Barros, N., J. Cole, L. Tranvik, Y. Prairie, D. Bastviken, V. Huszar, P. Giorgio, and F. Roland (2011), Carbon emission from hydroelectric reservoirs linked to reservoir age and latitude, Nat. Geosci., 4, 593-596, doi:10.1038/ ngeo1211.

Bergström, I., S. Mäkelä, P. Kankaaka, and P. Kortelainen (2007), Methane efflux from littoral vegetation stands of southern boreal lakes: An upscaled regional estimate, Atmos. Environ., 41, 339-351, doi:10.1016/ j.atmosenv.2006.08.014.

Borges, A., J. Vanderborght, L. Schiettecatte, F. Gazeau, S. Ferrón, B. Delille, and M. Frankingnoulle (2004), Variability of gas transfer velocity of $\mathrm{CO}_{2}$ in a macrotidal estuary (the Sceldt), Estuaries, 27, 593-603, doi:10.1007/BF02907647.

Chen, H., Y. Wu, X. Yuan, Y. Gao, N. Wu, and D. Zhu (2009), Methane emissions from newly created marshes in the drawdown area of the Three Gorges Reservoir, J. Geophys. Res., 114, D18301, doi:10.1029/ 2009JD012410.

Chen, H., X. Yuan, Z. Chen, Y. Wu, X. Liu, D. Zhu, N. Wu, Q. Zhu, C. Peng, and W. Li (2011), Methane emissions from the surface of the Three Gorges Reservoir, J. Geophys. Res., 116, D21306, doi:10.1029/ 2011JD016244.

Cullenward, D., and D. G. Victor (2006), The dam debate and its discontents: An editorial comment, Clim. Change, 75, 81-86, doi:10.1007/ s10584-006-9085-7.

Demarty, M., J. Bastien, A. Tremblay, R. Hesslein, and R. Gill (2009), Greenhouse gas emissions from boreal reservoirs in Manitoba and Québec, Canada, measured with automated systems, Environ. Sci. Technol., 43, 8908-8915, doi:10.1021/es8035658.

dos Santos, M., L. Rosa, B. Sikar, E. Sikar, and E. dos Santos (2006), Gross greenhouse gas fluxes from hydro-power reservoir compared to thermopower plants, Energy Policy, 34, 481-488, doi:10.1016/j.enpol.2004.06.015.

Duan, X., X. Wang, Y. Mu, and Z. Ouyang (2005), Seasonal and diurnal variations in methane emissions from Wuliangsu Lake in arid regions of China, Atmos. Environ., 39, 4479-4487, doi:10.1016/j.atmosenv.2005. 03.045 .

Duchemin, E., M. Lucotte, R. Canuel, and A. Chamberland (1995), Production of the greenhouse gases $\mathrm{CH}_{4}$ and $\mathrm{CO}_{2}$ by hydroelectric reservoirs of the boreal region, Global Biogeochem. Cycles, 9, 529-540, doi:10.1029/ 95GB02202.

Dunfield, P., R. Knowles, R. Dumont, and T. Moore (1993), Methane production and consumption in temperate and subarctic peat soils: Response to temperature and pH, Soil Biol. Biochem., 25, 321-326, doi:10.1016/ 0038-0717(93)90130-4.

Ferrón, S., T. Ortega, A. Gómez-Parra, and J. M. Forja (2007), Seasonal study of dissolved $\mathrm{CH}_{4}, \mathrm{CO}_{2}$ and $\mathrm{N}_{2} \mathrm{O}$ in a shallow tidal system of the bay of Cádiz (SW Spain), J. Mar. Syst., 66, 244-257, doi:10.1016/j. jmarsys.2006.03.021.

Frankenberg, C., J. F. Meirink, M. van Weele, U. Platt, and T. Wagner (2005), Assessing methane emissions from global space-borne observations, Science, 308, 1010-1014, doi:10.1126/science.1106644.

Guérin, F., G. Abril, D. Serça, C. Delon, S. Richard, R. Delmas, A. Tremblay, and L. Varfalvy (2007), Gas transfer velocities of $\mathrm{CO}_{2}$ and $\mathrm{CH}_{4}$ in a tropical reservoir and its river downstream, J. Mar. Syst., 66, 161-172, doi:10.1016/ j.jmarsys.2006.03.019.

Guo, X., X. Huang, and K. Xu (2007), The natural and geological environment in the Three Gorges Reservoir, in Prevention and Treatment of Landslide and Collapse Geological Hazards in Three Gorges Reservoir Project Area [in Chinese], edited by G. Wu and Z. Huang, pp. 2-16, China Waterpower, Beijing.

Huttunen, J., T. Väisänen, S. Hellsten, H. Nykänen, H. Jungner, A. Niskanen, M. Virtanen, O. Nenonen, and P. Martikainen (2002), Fluxes of $\mathrm{CH}_{4}, \mathrm{CO}_{2}$, and $\mathrm{N}_{2} \mathrm{O}$ in hydroelectric reservoirs Lokka and Porttipahta in the northern boreal zone in Finland, Global Biogeochem. Cycles, 16(1), 1003, doi:10.1029/2000GB001316.

Iqbal, J., S. Lin, R. G. Hu, and M. L. Feng (2009), Temporal variability of soil-atmospheric $\mathrm{CO}_{2}$ and $\mathrm{CH}_{4}$ fluxes from different land uses in midsubtropical China, Atmos. Environ., 43, 5865-5875, doi:10.1016/j. atmosenv.2009.08.025.

Jiang, C., Y. Wang, Q. Hao, and C. Song (2009), Effect of land-use change on $\mathrm{CH}_{4}$ and $\mathrm{N}_{2} \mathrm{O}$ emissions from freshwater marsh in northeast China, Atmos. Environ., 43, 3305-3309, doi:10.1016/j.atmosenv.2009.04.020.

Juutinen, S., J. Alm, P. Martikainen, and J. Silvola (2001), Effects of spring flood and water level drawn-down on methane dynamics in the littoral zone of boreal lakes, Freshwater Biol., 46, 855-869, doi:10.1046/ j.1365-2427.2001.00721.x.

Juutinen, S., J. Alm, T. Larmola, J. T. Huttunen, M. Morero, S. Saarnio, P. J. Martikainen, and J. Silvola (2003a), Methane $\left(\mathrm{CH}_{4}\right)$ release from littoral wetlands of boreal lakes during an extended flooding period, Global Change Biol., 9, 413-424, doi:10.1046/j.1365-2486.2003.00595.x.

Juutinen, S., J. Alm, T. Larmola, J. T. Huttunen, M. Morero, P. J. Martikainen, and J. Silvola (2003b), Major implication of the littoral zone for methane release from boreal lakes, Global Biogeochem. Cycles, 17(4), 1117, doi:10.1029/2003GB002105.

Keller, M., and R. Stallard (1994), Methane emission by bubbling from Gatun Lake, Panama, J. Geophys. Res., 99, 8307-8319, doi:10.1029/ 92JD02170.

Liu, H., P. Zhao, P. Lu, Y. Wang, Y. Lin, and X. Rao (2008), Greenhouse gas fluxes from soils of different land-use types in a hilly area of south China, Agric. Ecosyst. Environ., 124, 125-135, doi:10.1016/j.agee.2007. 09.002 .

Lu, F., X. Wang, B. Han, Z. Ouyang, and H. Zheng (2010), Straw return to rice paddy: Soil carbon sequestration and increased methane emission [in Chinese with English abstract], Yingyong Shengtai Xuebao, 21, 99-108.

$\mathrm{Lu}, \mathrm{F}$., et al. (2011), Preliminary report on methane $\left(\mathrm{CH}_{4}\right)$ emissions from the Three Gorges Reservoir (TGR) in the summer drainage period, J. Environ. Sci., 23(12), 2029-2033, doi:10.1016/S1001-0742(10)60668-7.

Marani, L., and P. C. Alvalá (2007), Methane emissions from lakes and floodplains in Pantanal, Brazil, Atmos. Environ., 41, 1627-1633, doi:10.1016/j.atmosenv.2006.10.046.

Merbold, L., W. L. Kutsch, C. Corradi, O. Kolle, C. Rebmann, P. C. Stoy, S. A. Zimov, and E. D. Schulze (2009), Artificial drainage and associated carbon fluxes $\left(\mathrm{CO}_{2} / \mathrm{CH}_{4}\right)$ in a tundra ecosystem, Global Change Biol., 15, 2599-2614, doi:10.1111/j.1365-2486.2009.01962.x.

Qi, W., et al. (2002), Comprehensive indexes of nutritive salt and organic contaminant, in Monitoring and Analysis Methods for Water and Wastewater [in Chinese], 4th ed., edited by S. Wu, pp. 236-284, Chinese Environ. Sci., Beijing.

Sitaula, B. K., I. R. Bakken, and G. Abrahamsen (1995), $\mathrm{CH}_{4}$ uptake by temperature forest soil: Effect of $\mathrm{N}$ input and soil acidification, Soil Biol. Biochem., 27(7), 871-880, doi:10.1016/0038-0717(95)00017-9.

Smith, L. K., W. M. Lewis, J. P. Chanton, G. Cronin, and S. K. Hamilton (2000), Methane emissions from the Orinoco River floodplain, Venezuela, Biogeochemistry, 51, 113-140, doi:10.1023/A:1006443429909.

Soumis, N., E. Duchemin, R. Canuel, and M. Lucotte (2004), Greenhouse gas emissions from reservoirs of the western United States, Global Biogeochem. Cycles, 18, GB3022, doi:10.1029/2003GB002197.

St. Louis, V. C., C. Kelly, E. Duchemin, J. W. M. Rudd, and D. M. Rosenberg (2000), Reservoir surface as sources of greenhouse gases to the atmosphere: A global estimate, BioScience, 50, 766-775, doi:10.1641/ 0006-3568(2000)050[0766:RSASOG]2.0.CO;2.

Tang, X., S. Liu, G. Zhou, D. Zhang, and C. Zhou (2006), Soil-atmospheric exchange of $\mathrm{CO}_{2}, \mathrm{CH}_{4}$, and $\mathrm{N}_{2} \mathrm{O}$ in three subtropical forest ecosystems in southern China, Global Change Biol., 12, 546-560, doi:10.1111/j.13652486.2006.01109.x. 
Thérien, N., and K. Morrison (2005), Production of GHG from the decomposition of in vitro inundated phytomass and soil, in Greenhouse Gas Emissions-Fluxes and Processes: Hydroelectric Reservoirs and Natural Environments, edited by A. Tremblay et al., pp. 315-338, Springer, New York, doi:10.1007/3-540-26643-7 13 .

Topp, E., and E. Pattey (1997), Soils as sources and sinks for atmospheric methane, Can. J. Soil Sci., 77, 167-177, doi:10.4141/S96-107.

Tremblay, A., J. Therrien, B. Hamlin, E. Wichmann, and L. LeDrew (2005), GHG emissions from boreal reservoirs and natural aquatic ecosystems, in Greenhouse Gas Emissions-Fluxes and Processes: Hydroelectric Reservoirs and Natural Environments, edited by A. Tremblay et al., pp. 209-232, Springer, New York, doi:10.1007/3-540-26643-7 8.

Wuebbles, D., and K. Hayhoe (2002), Atmospheric methane and global change, Earth Sci. Rev., 57, 177-210, doi:10.1016/S0012-8252(01) 00062-9.

Ye, Y., C. Yin, and Y. Ye (2006), On the landscape planning mode of the ebbing area of the Three Gorges - The landscape design of the ebbing area on the north land of Wanzhou, Chongqing [in Chinese with English abstract], Art Design, 9, 118-119.
Zhao, Y., Y. Zeng, R. Wu, Q. Wang, C. Yuan, and Z. Xu (2011), Observation on greenhouse emissions from Xiangxi River in Three Gorges region [in Chinese with English abstract], Adv. Water Sci., 22(4), 546-553.

Zheng, F., et al. (2011a), Effects of elevated zone concentration on methane emission from a rice paddy in Yangtze River Delta, China, Global Change Biol., 17, 898-910, doi:10.1111/j.1365-2486.2010.02258.x.

Zheng, H., X. Zhao, T. Zhao, F. Chen, W. Xu, X. Duan, X. Wang, and Z. Ouyang (2011b), Spatial-temporal variations of methane emissions from the Ertan hydroelectric reservoir in southwest China, Hydrol. Processes, 25, 1391-1396, doi:10.1002/hyp.7903.

Zhou, Y., X. Wang, Q. Wu, F. Lu, and J. Qiu (2010), The characteristics of the drawdown areas of Three Gorges Reservoirs, in Ecological Vulnerability and Protection in the Drawdown Area of the Three Gorges Reservoir, edited by L. Liu, pp. 30-37, Chinese Environ. Sci., Beijing.

Zhuang, Q., J. Melack, K. Walter, C. Butenhoff, and M. Khalil (2009), Global methane emissions from wetlands, rice paddies and lakes, Eos Trans. $A G U, 90(5), 37$, doi:10.1029/2009EO050001. 